\title{
Volney and the science of morality in revolutionary France
}

\author{
Alexander Cook
}

\section{Abstract}

Today, Constantin François Volney (1757-1820) is an obscure figure. He was once one of the most notorious philosophers in Europe. Celebrated and reviled in equal measure, this philosopher, historian, linguist, travel writer and politician was for two generations the most widely read philosopher of the French Revolution. His work was banned in many countries, but it was distributed by networks of admirers across Europe and its colonial world. Throughout one of the most turbulent eras in European history, Volney sought to develop a philosophical system that would ground private morality and public governance in a scientific understanding of the physiology of the human body and the laws of collective life. His attempts to do so, and the context in which those attempts were made, shed light on the genealogy and early politics of the social sciences in Europe.

\section{Introduction}

The subject of this article would not normally be considered a 'key thinker' in the accepted sense of that term. Constantin-François Volney (1757-1820) is not often cited as one of the great figures of European intellectual tradition. He has inspired no continuous movement that professes devotion to his philosophy. We do not speak of 'Volneyism' as we speak of 'Marxism' or 'Kantianism'. From the perspective of canonical intellectual history, he is usually regarded as little more than a footnote. Yet I want to suggest in what follows that Volney can be thought of as a key thinker in another sense.

Today Volney is a relatively obscure figure in French history. He is known primarily to specialists on the 1789 Revolution or to students of European orientalism - a field in which he exercised considerable influence by virtue of his first book, an account of a three-year voyage to Egypt and Syria published in 
1787. ${ }^{1}$ Volney was, however, once one of the most notorious writers in Europe. As a consequence of a short book published in 1791, entitled Les Ruines, ou Méditation sur les révolutions des empires, he was internationally condemned as a religious infidel and a political incendiary. Even inside revolutionary France his work aroused controversy. Over ensuing decades dozens of books and pamphlets were written to combat his influence. Several of his works were banned. Yet, despite persistent hostility, his writings could be purchased in 14 languages. They were read, debated and strategically disseminated by supporters across Europe and the Americas. Indeed, while Volney developed increasing ambivalence towards the French Revolution, he became one of its major intellectual exports. Viewed from a global perspective, Volney was almost certainly the most widely read philosopher of the French Revolution until at least the 1830s. ${ }^{2}$ It is this that has led the literary critic Marilyn Butler to label Volney 'the Foucault of his day'. ${ }^{3}$ It is this, too, which means that, however obscure Volney has now become, this understudied philosopher can provide us with a key for unlocking, or understanding, issues in the intellectual and cultural history of his era. This essay is about one of those issues. It uses Volney as a case study for examining a quest to build a science of morality during the era of the French Revolution. More specifically, it uses Volney as a means of exploring one particular strategy for realising that quest. It is a strategy based on the desire to reconcile the selfish aspirations of individuals with the pursuit of the public good. For Volney, it was an attempt to align social life with natural law. Volney's efforts in this arena saw him become one of the most influential and controversial writers of his age.

Volney was born Constantin-François de Chassebeuf to a family of provincial lawyers in Craôn in north-western France. His mother died when he was two and his family life was, by his own account, unhappy. Resisting paternal pressure to study law, he devoted himself to philosophy and ancient history before moving to Paris in his early twenties to study medicine and, unusually,

1 Volney, C. F. 1787, Voyage en Syrie et en Egypte, Desenne, Paris.

2 According to estimates derived from the annual Bibliographie de la France, begun in 1811, Les Ruines never ranked lower than twenty-sixth position in the overall French bestseller lists in the years between 1816 and 1830. In the period from 1811 to 1850 in France, only Fénelon's Telemaque and the works of Voltaire and Rousseau consistently ranked higher than Les Ruines in popularity amongst publications containing substantial political or religious criticism. Among works published by revolutionaries, only Bernardin de Saint-Pierre's novel Paul et Virginie was more popular in France during the same period. See Lyon, M. 1983-86, 'Les best-sellers', in H. J. Martin and R. Chartier (eds), Histoire de l'édition française, [4 vols], Promodis, Paris, vol. III, pp. 369-79. Outside France, Volney's Ruines had few competitors for popularity among revolutionary texts.

3 Butler, M. 1990, 'Byron and the empire in the east', in A. Rutherford (ed.), Byron: Augustan and romantic, Macmillan, London, p. 71. 
Arabic. There he adopted the name Volney. ${ }^{4}$ And there he gained entry to the circles of philosophers such as Claude Adrien Helvétius and the Baron PaulHenri Thiry d'Holbach, where he was introduced to a world of salon philosophy and political intrigue that would shape his views throughout his life. ${ }^{5}$

Over the succeeding 40 years, Volney played several roles in French history: scholar, public moralist and politician. In the first capacity he was, even by the standards of his contemporaries, an impressive polymath. He published on ancient history, linguistics and historical methodology as well as political and moral philosophy. Famous as a travel writer, he wrote detailed studies of the Levant and the United States that combined an eye for geography and natural history with a penchant for social analysis.

Volney also played a part in the world of practical politics, although this was a world he came gradually to despise. He was an important player in the early course of the French Revolution as a confidant of Mirabeau and first Secretary of the Constituent Assembly in 1789. As a journalist, he helped, together with figures such as Sieyès, Petion and Brissot, to develop the political rhetoric that came to dominate agitation on behalf of the Third Estate. ${ }^{6}$ He was a founding member of the Jacobin Club, but he would become a staunch critic of Jacobin politics as it would later be understood. Like many of those who were too open in their criticisms, he was imprisoned in $1793 .{ }^{7}$ Disillusioned, he left France for America only to return in 1798 under the misguided suspicion that he was an agent of French ambitions for expansion in North America. ${ }^{8}$ In the same year, he contributed to the coup of 18 brumaire that brought Napoleon to power and effectively brought the Revolution to an end.

\footnotetext{
4 The reasons for his choice of pseudonym are unclear. According to Volney's friend Besnard it was an Arabic equivalent of Chasseboeuf (Besnard, Y. F. 1880, Souvenirs d'un nonagénaire, [2 vols], Lafitte, Marseille, vol. 1, p. 187). This is disputed by Arabists of my acquaintance. It has been suggested that it could be an adaptation of the Russian word for liberty or a compound of 'Voltaire' and 'Ferny' — the latter's residence in Switzerland. It could also have more obscure origins relating to Volney's family.

5 On those milieux, see Jaëcklé-Plunian, Claude and McMeekin, Sean A. 1999, Studies on Voltaire and the Eighteenth Century, The Voltaire Foundation, Oxford, p. 374; Guillois, A. 1894, Le Salon de Mme Helvétius: Cabanis et les idéologues, Levy, Paris; Kors, A. C. 1976, D'Holbach's Coterie: An enlightenment in Paris, Princeton University Press, NJ.

6 On Volney's role in the political agitations of 1788-89, see Barny, R. 1988, 'Les pamphlets du Volney', in J. Roussel (ed.), L'Héritage des lumières: Volney et les idéologues (actes du colloque d'Angers, 1987), Presse de l'Université d'Angers, France, pp. 17-28.

7 This internment was notionally for debt acquired during the sales of church and crown land in 1790 91, but Volney's release at the end of the Terror in 1794 gives some indication of the political nature of the internment. See Gaulmier, J. 1980 [1951], L'Idéologue Volney: Contribution à l'histoire de l'orientalisme en France, Slatkine, Geneva, pp. 289-98.

8 Volney's correspondence with the directory during this period indicates that, although he was certainly providing advice to the French on conditions in America, he was strongly against attempts to expand French power in North America. Mathiez, A. 1910, 'Lettres de Volney à la Révellière-Lepeaux, 1795-98', Annales révolutionnaires, vol. 3, pp. 161-94.
} 
Volney would serve as a senator during the Consulate and was made a count during the Empire. Yet he quickly lost his love for the regime. Although he had come to long for a degree of order in France, its price in lost liberty under Napoleon seemed to Volney too high to pay. ${ }^{9}$ Largely as a consequence, he welcomed the Bourbon Restoration in 1815. Once again, however, he was unable to restrain his discontent and he became a public figure of opposition. ${ }^{10}$ When he died, in 1820, he felt his country had learned much less than he had hoped from its years of social experimentation.

This history has not always won Volney friends. In the Jacobin/Marxist historiography that for many years dominated French scholarship on this period, Volney is often portrayed as a timid, bourgeois revolutionary-one too frightened to stay the course of a process he had helped to initiate. ${ }^{11}$ Yet there is little evidence to suggest that Volney's loss of faith in the course of the Revolution derived from a belief that its program had become too radical or democratic. What is clear is that he disliked the violence, the factionalism and the intolerance of dissent. He had a philosopher's queasiness about realpolitik.

Despite the range of Volney's activities, much of his labour was devoted to a single, if multifaceted, project: throughout his life he sought to discover and promote principles of civil and self-government that he believed could provide the basis for a stable, contented and prosperous social order. His pursuit of this project made him a significant figure in the development of the social sciences in France. Fresh from his imprisonment during the Terror, he was the Thermidorian government's first nominee to the Class of Political and Moral Sciences at the newly created Institut national in $1795 .{ }^{12}$ He was associated with a circle of thinkers, pejoratively labelled 'idéologues' by Napoleon, who did much to develop the conceptual and institutional framework of those sciences. ${ }^{13}$

9 Volney fell out with Napoleon over the reconquest of Saint-Domingue, over the Concordat and over the inauguration of the empire - the last leading Volney to attempt a public resignation from the Senate.

10 The last work published in his lifetime was a polemical attack on attempts to re-establish divine-right monarchy entitled L'Histoire de Samuel: Inventeur du sacre des rois (1819).

11 Thus Volney 'appartient très précisément à ce milieu du Haut-Tiers qui cherchera dans la convocation des états Généraux le moyen de jouer un rôle politique égal à sa puissance sociale et à ses capacités; mais non pas la subversion totale d'un état économique dont il était largement bénéficiaire' (Gaston-Martin 1934, 'Esquisse biographique', introduction to Volney, C.F. Loi Naturelle, Paris, p. 5); or Volney represents 'la direction bourgeoise du mouvement révolutionnaire contre les tendances les plus populaires' (Barny, R. 'Les pamphlets de Volney', in Roussel [ed.], L'Héritage des Lumières, p. 23); or Volney revealed an 'étroitesse d'esprit des Lumières bourgeoises vis-à-vis des phénomènes historiques d'origine collective, populaire' (Deneys, $\mathrm{H}$. 1991, 'La chronologie asiatique ancienne contre le “Roman Juif"', in M. Matucci [ed.], Gli 'Idéologues' e la Revoluzione, Pacini, Pisa, p. 203); or Volney displayed a 'recul contre l'irruption des masses sur la scène historique' (Gusdorf, G. 1978, La Conscience révolutionnaire: Les idéologues, les sciences humaines et la pensée occidentale, Payot, Paris, p. 297).

12 Etat de l'Institut de France (2000, Institut de France, Paris, p. iv).

13 After falling out with Volney and other members of the group, Napoleon claimed the term 'idéologues', as distinct from Tracy's 'idéologistes', was his own invention: 'Les métaphysiciens sont mes bêtes noires. J'ai rangé tout ce monde-là sous la denomination d'idéologues...le mot a fait fortune, je crois parce qu'il venait de moi...Comment pourrais je m'entendre avec eux pour gouverner ainsi qu'ils le prétendent...ils ont la rage 
Members of the group included Antoine-Louis-Claude Destutt de Tracy, whose ambition for a science of 'idéologie' provided inspiration for the collective nounand, for reasons we will touch on, the future Marxist concept of 'ideology' ${ }^{14}$ It also included the influential medical philosopher Pierre-Jean-Georges Cabanis, whose attempts to link physiological research to social philosophy would play an important role in the development of early nineteenth-century French social science. $^{15}$

There were important philosophical and political distinctions within this group. Volney, unlike Cabanis, for example, was committed to a notion that human difference was largely the product of environment not heredity. ${ }^{16}$ He shared with these men, however, an ambition to develop a politico-moral science that could provide an alternative to both the traditional authority structures of the ancien régime and the violent factional conflicts that had come to afflict the French Revolution.

The bases of this science were seen to lie in an analysis of the origins of ideas and an anatomy of the will. It was hoped that a purified theory of knowledge would permit a new understanding of humanity in relation to its physical and social environment. This in turn would provide guidance for an optimised system of public politics and private ethics designed to maximise collective and individual happiness. The roots of their approach lay in the 'associationist' epistemology of John Locke, as developed in France by Etienne Bonnot de Condillac, and in the 'sensualist' psychology that had been combined with the former in the work of figures such as Helvétius and Holbach. In Volney's case, this aspiration yielded a program for a detailed comparative study of past and present civilisations aimed at detecting the political, cultural and moral conditions conducive to social health and decay. The goal was to develop what Volney called a 'physiological science of government'. ${ }^{17}$

\footnotetext{
de se mêler de mon gouvernement; les bavards!' This public rhetorical battle led the 'idéologues', in return, to label Napoleon an 'idéophobe' (Iung, T. [ed.] 1882, Lucien Bonaparte et ses Mémoires, 1775-1840, [3 vols], Charpentier, Paris, vol. II, pp. 243-4).

14 The term was pioneered in 1797-98. The key text, although a late one, was Destutt de Tracy's five-volume Eléments d'idéologie (1817-18).

15 Cabanis' Rapports du physique et du moral de l'homme (1802) was a central work shaping period attempts to develop a physico-medical model of man as a private and social being.

16 Volney never explicitly endorsed the extreme Helvétian position that 'education peut tout', but both his political and ethnographic writings persistently emphasised underlying human unity, diversified by historical context. The work of Cabanis, in contrast, while it certainly acknowledged the power of society to shape the individual, showed a developed interest in biological human variation. Throughout his career, Volney remained an independent figure, sometimes to the frustration of his friends. Destutt de Tracy wrote to Cabanis in 1806 remarking that he wished Volney 'soit un peu plus idéologiste', although he added that 'après lui et nous il serait plus facile de l'être' (Guillois, Salon, p. 199).

17 Volney, C. F. 1989-98 [1795], 'Leçons d'Histoire prononcées à l'Ecole Normale', in H. and A. Deneys (eds), C. F. Volney, Euvres, Fayard, Paris, vol. I, pp. 572-3. All translations from French editions of Volney's writings in this essay are my own.
} 
Aspects of this project contributed to a range of intellectual and political programs in France - and more broadly across Europe - throughout the first half of the nineteenth century. Yet from the beginning it was a subject of controversy. For many on the right, Volney was a dangerously utopian political rationalist of the kind that precipitated the revolutionary catastrophe. For some critics on the left, Volney's thought would eventually come to be associated with a narrow individualism and perhaps a latent social conservatism, which they believed had prevented the Revolution from fulfilling its promise. Thinkers across the spectrum of politics objected to the perceived 'materialism' of this system, its apparent refusal to concede a place for religion in the social order and a supposedly undignified emphasis on sensual pleasure as the goal of human action.

It is in large part a result of the cumulative effect of these criticisms that Volney came to be portrayed in many quarters as little more than a minor lateEnlightenment philosopher of dubious character and questionable political associations. ${ }^{18}$ It is a testament to their impact that, despite an accumulating body of evidence for Volney's historical importance, he has been the subject of only one scholarly monograph, published in $1951 .{ }^{19}$ While Volney has attracted somewhat more interest in recent years, he remains a figure whose place in history accords poorly with his place in historiography.

Among intellectual historians, Volney tends to be understood, together with the other idéologues, as a bridging figure between the natural-law paradigms of the eighteenth century and the social-scientific ones that would emerge in the early nineteenth century. ${ }^{20}$ Among cultural historians, Volney tends to be understood as a bridging figure between the Voltairean scepticism of the French philosophes and the melodramatic literary mode of the romantics. ${ }^{21}$ Among French political historians, Volney tends to be presented either as a species of liberal philosopher, advocating a society of private conscience and

18 This perception is evident in an essay by Sainte-Beuve, which became the most influential treatment of Volney in the nineteenth century. Although Sainte-Beuve declared Volney the most original thinker of the school of Helvétius and Holbach, he distanced himself from Volney's theories on morality, psychology and religion - collectively characterised as the author's 'delit sociale' (1853, Causeries $d u$ Lundi, Third edition, Paris, vol. VII, pp. 389-433). See also Berger, E. 1852, 'Volney et ses CEuvres', Revue de l'Anjou, vol. 1, pp. 212-24, 254-76.

19 Gaulmier, L'Idéologue Volney. Gaulmier cleared a path through much accumulated myth about the author. He established the basic outlines of his political and private life and assembled an array of sources that has provided the basis for all subsequent commentary.

20 The most systematic presentation of this view is Kaiser, T. 1976, The idéologues: from enlightenment to positivism, Unpublished PhD dissertation, Harvard University, Cambridge, Mass. See also, Manuel, F. 1956, 'From equality to organicism', Journal of the History of Ideas, vol. 17, pp. 54-69.

21 Mongland, A. 1930, Le Préromantisme français, Arthaud, Grenoble, vol. I, pp. 161-4; Ehrard, J. 1991, 'Volney ou la révolution mélancolique', in Bernard-Griffiths and Michaud (eds), Revolutions, and the Advent Resurrections. Essays in honor of Paul Viallaneix, Sedes, Paris, pp. 7-16; McCalman, I. 1994, 'The infidel as prophet: William Reid and Blakean radicalism', in S. Clark and D. Worrall (eds), Historicizing Blake, Macmillan, London, p. 33. 
private property, or as an early exemplar of an emergent species of technocratic philosophy of the kind later advocated by Auguste Comte - a philosophy in which government by scientific experts would substitute for the uncertainties of democratic process. ${ }^{22}$ Elsewhere in the world, however, Volney is often understood as a radical democrat advocating popular sovereignty and popular rights. ${ }^{23}$ In all these cases, Volney's failure to sit comfortably within established categories is suggestive of limitations within the categories themselves, and of an absence of detailed study of the sources.

To understand Volney, we need to understand something of his intellectual and social context. Volney's key concerns were generated by an attempt to meet the challenges of contemporary French history as he understood them. To do so, he used a matrix of political, social and moral thought inherited from pre-revolutionary debates which concerned the possibility of overcoming the perceived tendency of human societies towards entropy - an inevitable decline through decadence into anarchy or despotism. ${ }^{24}$ These debates, whose origins can be traced back at least to Aristotle, developed a particular urgency in the eighteenth century. The causes of this urgency were complex. In part, they suggest a loss of confidence in the integrating power of traditional forms of temporal and spiritual authority. In part, too, they reflect anxiety about social changes linked with the development of commercial society.

\footnotetext{
22 The vocabularies used differ slightly between these historians. Keith Baker claims that a 'tension between scientific elitism and democratic liberalism' lies at the heart of Condorcet's philosophy. He suggests, however, that Condorcet consciously worked to resolve this tension (Baker, K. M. 1975, Condorcet: From natural philosophy to social mathematics, Chicago University Press, Ill., p. 386). Welch refers to a tension between 'constitutionalism' and 'scientism' inside a philosophy that is best considered a 'transitional movement in liberalism' analogous to utilitarianism in England (Welch, C. B. 1984, Liberty and Utility: The French idéologues and the transformation of liberalism, Columbia University, New York, pp. 3, 195). For Staum, it is a tension between 'liberalism' and 'technocracy' in which the former is embodied in a concern for 'rights and guarantees' and the latter by a utopian vision of a society in which the rational calculation of ends would replace democratic conflict (Staum, M. 1996, Minerva's Message: Stabilizing the French Revolution, McGillQueens University, Montreal, p. 4).

23 On the international reputation of Volney, see: Cook, A. 2007, 'Reading revolution: towards a history of the Volney vogue in England' in Charle et al. (eds), Anglo-French Attitudes: Comparisons and transfers between English and French intellectuals since the eighteenth century, Manchester University, pp. 125-46. See also Thompson, E. P. 1980 [1963], Making of the English Working Class, Penguin, London, pp. 107-8; L. Jobim, 'L'Oeuvre de Volney et l'établissement du libéralisme au Portugal', in Roussel, L'Héritage des Lumières, pp. 405-13; and Moses, W. 1998, Afrotopia: The roots of African-American popular history, Cambridge University Press, UK, pp. 6, 55, 83-94.

24 This is classically expressed in the oft-discussed 'Polybian cycle' (after the Greek historian Polybius), which provided the matrix not only for much classical historiography but for much early modern historical writing.
} 
Volney's solution to the problem of entropy was to seek a means of anchoring society by harmonising it with the natural needs and inclinations of human beings. In this sense, he belonged to a tradition of eighteenth-century philosophy that argued that society would be more or less perfect as it approximated to, or deviated from, a certain 'natural form'. Yet Volney was no champion of primitive man or primitive society. He ridiculed the concept of the 'noble savage'. He despised Rousseau. ${ }^{25} \mathrm{He}$ believed that it was only through historical progress and scientific advance that humanity could learn to live in accordance with nature. In this sense, Volney was a modernist. He was, however, also a republicanin the eighteenth-century sense-and much of his political thought can be understood as an attempt to make republicanism viable in the modern world.

It was a widespread axiom of early modern political theory - from the time of Machiavelli to Montesquieu or Rousseau - that republican politics necessitated a small community with an economically and culturally homogenous citizenry. It was only in this environment that a sovereign people could be expected to cultivate virtú - the patriotic civic mentality that alone could provide the solidarity necessary for harmony within the State and unity against foreign foes. ${ }^{26}$ By the late eighteenth century, it was widely accepted that contemporary society did not generate this crucial sentiment. The division of labour, the rise of commerce and the spread of material prosperity meant that modern men, not to mention modern women, were too individualistic, too egoistic, to submit to the rigorous demands of republican life. ${ }^{27}$

For some, this made republican politics folly in the modern age. For others, it meant the task of political legislation was to restore virtue to its rightful place. Others decided that alternative means had to be found for binding the individual to the collective - means requiring less rigorous notions of virtue and fewer demands for self-sacrifice. This position was the one adopted by Volney. It is for this reason that the major polemical targets of his work (apart from kings, clerics and aristocrats) were philosophers such as Rousseau, Mably and Montesquieu, who insisted that republican government must live or die by its capacity to instil a culture of classical virtue in its citizenry.

25 In the Loi naturelle (1794), a passage implicitly directed against the Rousseauist account of history in the Discours sur l'origine d'inegalité claims that the 'sauvage' is an 'animal brute, ignorant ou une bête méchante et féroce à la manière des ours et des orang-outangs' (Volney, Euvres, vol. I, p. 549). An account of native Americans in Volney's Tableau du climat et sol des etats unis (1808) was also explicitly constructed as a polemic against the discourse of the noble savage (ibid., vol. II, pp. 335-71).

26 As Montesquieu defined it in 1748, this virtue entailed 'de l'amour pour la patrie, du désir du vraie gloire, du renoncement à soi-même, du sacrifice de ses plus chérs intérêts' (de Montesquieu, C. L. 1768 [1748], De l'Esprit des lois: Nouvelle edition, revue, augmentée et corrigée par l'auteur, [4 vols], Nourse, London, vol I, p. 46).

27 As Montesquieu put it - prefiguring Benjamin Constant's famous definition of modern liberty by more than half a century - the difference between ancients and moderns was that while once 'on étoit libre avec les loix', now 'on veut être libre contre elles' (ibid., vol. I, p. 42). 
It is possible to trace many influences on Volney's intellectual development. The chief factor shaping his approach to these issues was, however, his adoption, and to some extent his adaptation, of a politico-moral project articulated most clearly by Claude-Adrien Helvétius, whose ghost still presided over the salon at Auteuil where Volney passed much of his time. For Helvétius, the universal challenge of government was the problem of aligning individual with collective interests. It was only by appealing to the self-interest of citizens that government could motivate them in desirable directions and, ultimately, interest them in the survival of the State. The goal was to create conditions in which the private pursuit of happiness would coincide with the practice of virtue - the latter being understood as the performance of actions that promote the collective good of the community. Only in this way could a prosperous, harmonious and secure state be built on foundations that took into account the 'real' motives of human action. ${ }^{28}$

This psychological individualism is a major reason why Volney, together with the other idéologues, with Jeremy Bentham in England and predecessors such as Holbach and Helvétius, have persistently been associated by intellectual historians with an atomistic model of society and an instrumental view of human relations. It is frequently suggested that this model of the relationship of the individual to society reflects a calculating, contractually-oriented attitude to social interaction that corresponds at some deep level with the experience of commercial society, or that it helps to justify the existence of such a society. ${ }^{29}$ While there is certainly truth to the suggestion that this model of the individual can be found in various apologies for unregulated capitalism, it is less clear that it inevitably produced philosophy of this kind. In the case of Volney at least, the model seems designed to serve different purposes. As we will see, it was certainly used, on occasion, to pursue other goals.

To explain what I mean, I want to elucidate Volney's thought a little by offering a brief discussion of Volney's most famous book, The Ruins.

\footnotetext{
28 The pioneering text here was Helvétius's controversial work De l'Esprit (1758) - a work that set out to demonstrate how all human behaviour derived from the pursuit of self-interest and that sought to demonstrate how society could be reorganised in a manner to harness that motivation for the collective good. The work was condemned by the Sorbonne, it led to the sacking of the royal censor and it caused considerable unease among many of Helvétius's nominal allies among the parti philosophique (see Smith, D. W. 1966, Helvétius: A study in persecution, Clarendon, Oxford).

29 This was the position of the mature Marx: 'The apparent stupidity of merging all the manifold relationships of people in the one relation of usefulness, this apparently metaphysical abstraction, arises from the fact that, in modern bourgeois society, all relations are subordinated in practice to the one abstract monetary-commercial relation' ([1846] 'The German ideology', in D. McLellan [ed.], Karl Marx: Selected writings, Oxford University Press, UK, pp. 201-2). This position would become the dominant sentiment within Marxian historiography. Its classic expression in intellectual history can be found in an account of the origins of this tradition: Macpherson, C. B. 1962, The Political Theory of Possessive Individualism: Hobbes to Locke, Clarendon, Oxford.
} 


\section{III}

The Ruins often seems a curious book to modern readers. It blends large passages of political and moral philosophy with a heavily poetic style, a first-person narrator and a fictional structure that includes dream sequences, genies and revelations about a future world. The narrative is set in 1784, before the French Revolution. The narrator is a traveller in the Levant - as Volney had been at the time. While wandering in the desert, he stumbles across the ruins of the ancient city of Palmyra. Faced with this spectacle of decay, the narrator experiences a metaphysical crisis. He concludes that a blind fate or some hostile god must rule the destiny of human kind; all is futility. ${ }^{30}$ At this moment, roused by the narrator's lament, a 'genie' appears from the ruins. To console the narrator, the genie promises to reveal the hidden logic of human history. Humanity, he explains, is certainly subject to superior powers, but these powers are not the caprices of 'fantastic and bizarre beings'. Rather, 'like the world, of which he is a part, Man is ruled by Natural laws' ${ }^{31}$ To demonstrate this fact the genie raises the narrator into the heavens, revealing a panorama of life on Earth. ${ }^{32}$ In a series of passages reminiscent of Buffon, human history is revealed as a subset of natural history. ${ }^{33}$

The genie goes on to explain that natural law reveals itself in essential properties imprinted on human beings. These derive from the fact that, for humans, any action dangerous to their existence causes pain or sadness, while any favourable action causes pleasure and happiness. ${ }^{34}$ From this it follows that 'self-love, the desire for happiness, the aversion to misery' are 'the essential and primordial laws, imposed on man by Nature itself'; it is these that 'the designing power, whatever it may be' has 'established to govern man'. ${ }^{35}$

On this basis, the genie proceeds to set out a theory of history in which the rise and decline of states are related to the justice of their internal organisation. The ruin of ancient civilisations was a consequence of the failure of both legislators and peoples to understand their true interests and the means to pursue them within the logic of social life. The genie's claim is that, in the long term, a society is only as strong as the number of individuals with a personal interest in

\footnotetext{
30 Volney, Euvres., vol. I, p. 179.

31 Ibid., p. 195.

32 Ibid., p. 189.

33 In a footnote, Volney explicitly embraced the idea of human history as part of natural history, suggesting that Buffon's attempt to relate the two 'ne fait que rendre saillante notre ignorance actuelle' (Volney, Euvres, vol. I, p. 392). Buffon had insisted that humanity had another history, by virtue of its soul, that rendered it irreducible to natural history. For thinkers such as Diderot and Holbach, and also for Volney, humanity was very much a part of nature. On the naturalisation of history, see Duchet, M. 1995 [1971], Anthropologie et histoire au siècle des lumières, Paris, pp. 425-35.

34 Volney, Euvres, vol. I, p. 196.

35 Ibid., vol. I, p. 196.
} 
maintaining it. The lesson for legislators is that injustice is an act of imprudence. Throughout history, civilisations rise on the basis of common interests and mutual needs. They thrive as long as they manage to service those interests and meet those needs. Their decline sets in as soon as one section of that society begins to pursue short-term gain at the expense of the collective good.

The Ruins depicts the history of social conflict as the perpetual battle of two classes: the 'privileged classes', parasites who wish to live off the labour of others, and the 'people', consisting of those who contribute by their labour to the national prosperity. ${ }^{36}$ Volney claimed that 'all vices, all political disorders reduce to this: men who do nothing and devour the substance of others' ${ }^{37}$ The origin of this conflict is unenlightened 'amour-propre' - an imprudent desire to accumulate luxuries and leisure at the expense of others. It is stimulated by an ignorance of long-term interests. Thus, 'Cupidity, daughter and companion of ignorance', has become 'the cause of all the evils that have desolated the Earth' ${ }^{38}$ The short-term consequence is that the strong unite to dominate the weak and steal the products of their labour. The long-term consequence has been an endless series of societies degenerating towards instability and ruin.

At last, however, an opportunity had arisen to break this cycle. The prerequisite for this achievement, according to the genie, was the enlightenment of The People concerning its true strength and interests and the enlightenment of legislators concerning the principles of good government. With the progress of science and, crucially, the invention of the printing press, this development was finally conceivable. For Volney, the engine of modernity was not the advancing division of labour, the technical mastery of nature or the emergence of a state monopoly of violence. It was a revolution in communication. This revolution would lead, inevitably if gradually, to the enlightenment of the entire species. This, in turn, would lead by an ineluctable logic to its moral elevation: 'through experience Man will enlighten himself; through trial and error he will reform himself; he will become wise and good because it is in his interest to be so.' In the end, all would recognise that individual welfare is tied to the welfare of society'. ${ }^{39}$ The result, according to the genie, would be that eventually 'the entire species will become a great society, one family, governed by the same spirit, by common laws, and enjoying all the happiness of which human nature is capable'. ${ }^{40}$

36 Ibid., vol. I, p. 254. The 'people' comprised labourers, artisans, merchants and 'toutes les professions utiles à la societé'. Its enemy consisted largely of priests, courtiers and a rentier nobility, but it extended to include all the 'agents civils, militaires ou religieux du gouvernement'.

37 Ibid., vol. I, p. 391. A footnote claims that this opposition 'est l'analyse de toute société'.

38 Ibid., vol. I, p. 203.

39 Ibid., vol. I, pp. 243-4.

40 Ibid., vol. I, p. 245. 
The main obstacle to the global realisation of this vision of the future, according to the genie, was the division of humanity into mutually hostile religious camps - each committed to its own prejudices and unwilling to tolerate free debate. ${ }^{41}$ For this reason, almost half the book is devoted to an analysis of the genesis and history of religion, designed to reveal the common origins of religious belief while undermining the truth claims of all organised cults.

This intensive focus on religion has often seemed odd to modern readers. It has led some to see the book as one divided into multiple parts with different agendas. ${ }^{42}$ It is important to realise, however, that, for Volney, as for many of those who sought to establish a social science in this era-from Saint-Simon to Auguste Comte - social science was a means both of transcending and of functionally replacing the integrating and ordering function of religion.

For Volney, in its elementary form, religion was primitive science. It was a product of the first human attempts to understand and describe the universe. These attempts had been limited by the immaturity of reason and by the inadequacies of primitive language. ${ }^{43}$ In origin, the gods were nothing more or less than the physical forces of nature personified by the 'necessary mechanisms of language'. Their history was a narrative of natural phenomena traced by the 'first physicians who observed them'. ${ }^{44}$

With the beginning of agriculture, early humanity had noticed a correlation between the movement of the heavens and the cycles of nature. Supposing a causal relationship, philosophers had developed a system of religion based on the worship of the stars: 'sabéisme'. Naming the constellations after the terrestrial activities associated with their appearance, they had developed the zodiac in its modern form. Aquarius, the water carrier, represented the season of floods. Taurus represented the season in which, at certain geographical locations, crops were sown with the aid of a bull. Libra represented the spring equinox, and so on. Volney cited a memoir by his friend the ex-priest and mythographer, Charles Dupuis, to show that the origins of this system could be traced back 17000 years to the first Nilotic civilisations of upper Egypt. ${ }^{45}$

\footnotetext{
41 Ibid., vol. I, pp. 247-51.

42 Gaulmier, L'Idéologue Volney, p. 117.

43 The entire genealogy of religion provided in the second half of Les Ruines is really an exercise in analyse in the manner advocated by Condillaç. It was designed to illuminate the genesis of a particular body of concepts in relation to the physical sensibility of early humanity and to locate the points at which the linguistic means of representation had become an obstacle rather than a solution to the problems they were developed to solve (see de Condillaç, E. B. 1746, Essai sur l'origine des connoissances humaines, Mortier, Amsterdam, pp. 88-93). 44 'Ruines', in Volney, Euvres, vol. I, p. 318.

45 Ibid., vol. I, p. 323. The source for this theory was Dupuis, C. 1781, Mémoire sur les origines des constellations, Veuve Desaint, Paris. The dating alone was subversive of traditional Christian chronology, as Volney stressed in a footnote. The reasons assigned for this dating were based on an assumption that Libra originally rose at the vernal equinox. By a complex series of astronomical calculations, Dupuis had arrived at a date of $15194 \mathrm{BC}$ for the period of the original alignment. Contemporary commentators noticed similarities
} 
The proof of this genealogy, Volney argued, could be seen half-buried in the mythological systems that had survived across the world. These were allegories of natural processes filtered through a symbolic language derived, in large part, from the agrarian astronomy of ancient Egypt. The numerous stories of death and resurrection related to the natural cycles of the seasons and, in particular, to the passage of the Sun through the heavens. In Christianity, for example, the story of the Messiah as the conqueror of evil and the harbinger of the reign of virtue was merely one variant of an ancient myth that referred originally to the end of the season of dearth and the beginning of the season of plenty. The messiah figure was the Sun, born, according to ancient myth, at the winter solstice, passing a life in poverty and obscurity through the winter months, and resurrected in glory at the spring equinox. The secret of this natural code had been lost in the mists of time; the allegorical had been taken for the literal and modern religion had degenerated into a cynical exercise in social control. ${ }^{46}$

The key to creating a stable and prosperous society, in Volney's view, was for philosophy to develop a political and moral science that would provide a renovated system of ethics as a substitute for the pathological morality generated by the power-serving castes of the traditional priesthood. Based on the demonstrated union of individual and group interest (at least as it would exist in a properly organised society), this system would provide a more solid basis for morality than any system based on unproven metaphysical theories or vain appeals to self-sacrifice in the interests of the higher good-whether religious or secular.

The text culminates in a vision of the French Revolution, presented as a future event, in which it serves as a sign for the peoples of the world to rise up against their oppressors. A general assembly of peoples is summoned to determine the path to the future. It is here that religious hostility manifests itself most forcefully and it is in this forum that the demonstration of the history and failures of established religion is given. The book concludes with a demand that humanity should cease, at once, its fruitless metaphysical disputes. To live in peace and concord, it will be necessary to deprive religion and theology of all civil effects. ${ }^{47}$ All efforts in this realm must instead be transferred to 'an examination of the physical and constitutive aspects of man, of the movements and the affections that rule him in the individual and social state'. The result would be a knowledge of 'the laws by which Nature, herself, has founded [man's] happiness'. In a passage whose revealing irony seems to have escaped the

\footnotetext{
between Volney's theories on the genealogy of religion and those Dupuis would later set out in his sevenvolume Origine de tous les cultes, ou Religion universelle (1795, Agasse, Paris). It has been widely suggested that Volney might have seen the manuscript of the longer work and essentially took his theories from Dupuis. This is quite possible, although both authors shared sources belonging to a wider debate.

46 Volney, Euvres, vol. I, chs xxi-xxiii of 'Les Ruines'.

47 Ibid., vol. I, p. 378.
} 
author, the text concludes with an appeal from the peoples of the world to the legislators of the regenerated French nation: 'teach us, after so many religions of illusion and error, the religion of evidence and of truth!' ${ }^{48}$

In 1793, Volney published a small additional tract designed to do just this. It was entitled The Law of Nature, or Catechism of the French Citizen (note the use of the term 'catechism'). It was an attempt to set out systematically the ethical system described above. It claimed to show how all the virtues - private and socialcould be rationally justified to individuals as the behaviour recommended by an enlightened knowledge of private interest. Moderation of physical appetite was justified by the natural desire to preserve the body. ${ }^{49}$ Sociable behaviour was justified by the psychological and physical benefits derived by the individual from harmonious communal life. In order to ensure peace, it was necessary that social interaction should be governed by an ethic of what Volney called 'reciprocity'. More broadly, this implied that all interpersonal exchanges should be regulated by a principle of equity, such that none felt themselves to be disadvantaged by the exchange. This system was anchored in a negative construction of the Christian golden rule: do not do to others what you do not want done to you. ${ }^{50}$ As Volney expressed it in the final lines:

I conclude that...we are not happy except when we observe the rules established by nature for the purpose of our conservation; and that all wisdom, all perfection, all law, all virtue, all philosophy, consist in the practice of these axioms founded on our own organization:

Conserve yourself

Instruct yourself

Moderate yourself

Live for others so that they may live for you. ${ }^{51}$

The text also contained an explicit assertion of the religious character of the doctrine. Despite accusations of atheism, Volney claimed the 'sectarians of natural law' had 'stronger and more noble ideas of the Divinity than the hypocrites who calumniate them, because they do not soil it with a mixture of all the weaknesses and passions of humanity' ${ }^{.22}$ By the end of the 1790s, this tract had been appended to The Ruins. ${ }^{53}$

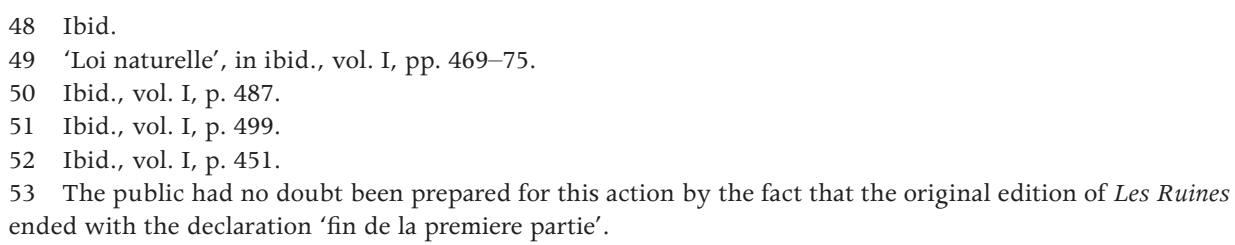


At the moment when The Ruins was published, France was in turmoil. The National Assembly had committed itself to enshrining a king who had attempted to flee the country. The Jacobin Club had fractured over the status of the monarchy in the aftermath of his flight. The National Guard had opened fire on demonstrators calling for proclamation of a republic. Martial law had been declared, newspapers suppressed and public demonstrations outlawed. There was violent debate over the criteria for voting rights for imminent elections. Caribbean colonies were in revolt as slaves demanded access to the rights of man. The attempt to nationalise the Catholic Church was visibly failing. In this context, these works can be seen as an attempt to protect the Revolution from derailment by internal and external conflict over issues of faith - both spiritual and temporal.

Ironically, in pursuit of this goal, Volney produced an analysis of history and an imaginative framework for thinking about human destiny that would foster acrimonious debate for generations.

\section{IV}

The first comment to make in relation to Volney's reception is that his period popularity relates in part to questions of form, rather than content. Volney was a key figure in transmitting a kind of literary vogue for ruin literature and a literary genre of secular prophecy to early nineteenth-century Europe. This was a subject of frequent comment among Volney's enemies. As one of them put it in 1825, the book 'is calculated to seduce the young and inexperienced...to them it is particularly dangerous, because it is written in the manner best adapted to their habits of thinking - it is a work of the imagination: a romance rather than a sober and patient investigation' ${ }^{54}$

These remarks were sometimes echoed by Volney's supporters. In part, then, Volney's story is a lesson about the poetics of political discourse and the artifice of propaganda in a nascent romantic age.

Beyond those remarks, however, the most striking thing for anyone who studies the patterns of Volney's reception during this period is the variety of contexts in which it was taken up. Among both admirers and critics, there was very little consensus as to the underlying philosophical, religious and political implications of this work.

54 Hails, W. A. 1825, Remarks on Volney's Ruins, or a Survey of the Ruins of Empires, Seeley \& Son, London, pp. 3-4. 
Predictably, one of the major roles of Volney's work was as a resource book for historical arguments designed to undermine biblical Christianity. It was assimilated to a corpus of texts used to provide accounts of the scientificallegorical character of early religion and its genesis in the study and worship of natural forces. As a consequence of this use, clergymen across Europe wrote fat books designed to refute Volney. ${ }^{55} \mathrm{~A}$ footnote, in which he had asserted that there was no more evidence for the historical existence of Jesus than for that of Hercules or Osiris, became one of the most debated annotations in European history.

This critical utility had, however, little necessary connection with the positive aspects of Volney's philosophy. And on this latter subject, interpretations varied. In religion, Volney was assimilated to certain kinds of monistic but providential deism. The ex-Baptist minister Elihu Palmer was one of Volney's greatest champions in the Anglophone world. Founder of the Deistical Society of New York, Palmer believed that theology must be 'rendered pure' by the 'science of ontology'. This would lead to recognition of 'an eternal Being, whose perfections guarantee the existence and harmony of the universe' ${ }^{56} \mathrm{He}$ claimed in his book Principles of Nature, or, A Development of the Moral Causes of Happiness and Misery amongst the Human Species (1801) that

[o]f all the books that ever were published, Volney's Ruins is preeminently entitled to the appellation of Holy Writ, and ought to be appointed to be read in Churches; not by his majesty's special command, but by the universal consent and approbation of all those who love nature, truth and human happiness. ${ }^{57}$

As it happens, Volney was read in churches - albeit of a somewhat unusual kind. Throughout the 1790s, public readings from The Ruins were common in

55 Volney's theological principles were subject to concerted critique in both France and Britain. Among the major works directed against Volney in English were: Simpson, D. 1793, An Essay on the Authenticity of the New Testament, designed as an answer to Evanson's Dissonance and Volney's Ruins, Bayley, Macclesfield, UK; Priestley, J. 1797, Observations on the Increase of Infidelity... To which are added, animadversions on the writings of several modern unbelievers, and especially the Ruins of $\mathrm{Mr}$ Volney, Dobson, London and Philadelphia; Priestley, J. 1797, Letters to Mr Volney, in answer to his book called Ruins, Dobson, London and Philadelphia; Testimonies to the Truth of Prophecy from the writings of Volney, 1800, London; Cockburn, W. 1804, Remarks on a Publication of M. Volney called 'The Ruins', Cambridge University Press, UK; Bellamy, J. 1819, The AntiDeist: Being a vindication of the Bible in answer to the publication called the Deist. Containing also a refutation of the erroneous opinions held forth in the Age of Reason, and in a recent publication entitled Researches on Ancient Kingdoms, Longman, London; Nolan, F. 1819, A Reply to Mr Volney's Ruins, Nolan \& Boone, London; Fragments of a Civick Feast: Being a key to Volney's Ruins, Bagster, London; Broughton, T. 1820, The Age of Christian Reason: Being a refutation of the theological and political principles of Thomas Paine, M. Volney and the whole class of political naturalists, Rivington, London; Emmett, J. B. 1823, Remarks on...Count Volney's New Researches into Ancient History, Alexander \& Son, York; Hails, W. A. 1825, Remarks on Volney's Ruins, Seeley \& Son, London.

56 Palmer, E. 1819, Principles of Nature, or, A Development of the Moral Causes of Happiness and Misery amongst the human species, Carlile, London, pp. 13, 11.

57 Ibid., p. 90. 
England in the free-thinking societies that formed the subject of a sensational exposé published in 1800: the Infidel Societies of the Metropolis. ${ }^{58}$ In the late 1820s and early 1830s, Volney's book, together with a juvenile imitation of it by Percy Shelley entitled Queen Mab, were the preferred texts in a course of Sunday 'infidel services' performed at the Blackfriar's Rotunda in London by an ex-Anglican minister, Robert Taylor-known to contemporaries as the 'devil's chaplain'. At their peak, these services attracted 4000 people. ${ }^{59}$ This kind of use for Volney was particularly prominent in Britain, where Volney attracted considerable interest among what we might consider the extreme fringe of the dissenting movement.

Religious dissent and, particularly, rationalist Socinianism were influential in campaigns for political reform in Britain throughout the eighteenth century. Its followers played an important role in the agitation that followed the early stages of the French Revolution. ${ }^{60}$ And Volney's call for the separation of religious and civil power precisely matched the major plank of dissenting politics during this period. Volney's version of natural religion moved well past the bounds of even the Socinian brand of Christianity. ${ }^{61}$ There was, however, widespread contemporary belief that radical dissent and natural religion were competing for the same market..$^{62}$ It is certainly clear that Volney made the greatest impact in Britain among social groups (skilled artisans, small businessmen and proprietors, workers in the printing trades) that had traditionally been the stronghold of 'rational dissent'. ${ }^{63}$

In France, too, Volney was assimilated to various forms of deistic or pantheistic religion, as well as to cults animated by an impulse towards religious syncretism. He was also highly influential within the speculative branch of French Freemasonry. As late as the 1880s, he was still being listed as a benefactor of humanity in French Freemasons' almanacs, together with Buddha, Zoroaster,

\footnotetext{
58 Reid, W. 1800, Rise and Dissolution of the Infidel Societies of the Metropolis, Hatchard, London, pp. iii, 8. 59 For a detailed account of Taylor's infidel services, see: McCalman, I. 1992, 'Popular irreligion in early Victorian England', in R. W. Davis and R. J. Helmstadter (eds), Religion and Irreligion in Victorian Society: Essays in honour of R. K. Webb, Routledge, London, pp. 51-67; Cook, 'Reading revolution', pp. 125-46.

60 The most famous examples are Richard Price and Joseph Priestley. See, for example, the former's famous Discourse on the love of our country delivered at the Old Jewry in 1789; and Priestley, J. 1791, Letters to Burke: A political dialogue on the general principles of government. The latter prompted the burning of Priestley's house and laboratory by a loyalist mob.

61 There was also little room for the dissenting notion of 'conscience' in the moral schemes advocated by Volney and his predecessors. Philp, M. 1986, Godwin's Political Justice, Duckworth, London, pp. 38-57.

62 Volney's first publisher in Britain was the official bookseller for the Unitarian Society. The Unitarian minister Joseph Priestley was one of Volney's most committed opponents during the 1790s. He explicitly lamented that fact that there were many instances of conversion to 'French principles' within the Arminian and Socinian communities (Priestley, Observations on the Increase of Infidelity, p. 141). Priestley returned to the subject of Volney in: Priestley, J. 1794, Letters Addressed to the Philosophers and Politicians of France, Dobson, Philadelphia, and Priestley, J. 1797, Letters to Mr Volney, Dobson, Philadelphia.

63 Thompson, Making of the English Working Class, pp. 29-58.
} 
Charles Dupuis and the physiocrat Dupont de Nemours. ${ }^{64}$ In France, however, it was more common to read Volney as an implicitly atheist thinker. This was certainly the view of theocratic Catholics such as Louis de Bonald, Felicité de Lammenais and Joseph de Maistre. In 1828, one commentator went so far as to claim that Volney's catechism 'reigns almost entirely where that of the church is no longer law' ${ }^{65}$

This was clearly an exaggeration. As I have already mentioned, Volney was from the outset subjected to serious attack. In both France and Britain, much of the philosophical criticism of Volney focused on his moral theory. The revolutionary deist Bernardin de Saint-Pierre and post-Protestant philosophers such as Madame de Stael and Benjamin Constant believed that a philosophy that sanctioned a psychology of self-interest and the pursuit of sensual pleasure was unable to sustain private or political virtue. They believed it diminished the dignity of the human struggle with the lower self. ${ }^{66}$ As Kantian moral philosophy gained ground in France during the nineteenth century - through the work of Victor Cousin and his allies - that became an increasingly dominant judgment. As one of Cousin's followers, J. P. Damiron, put it, 'if the principles of morality are physical principles, all human dignity is destroyed' ${ }^{67}$ In 1820 , the legal journal Themis carried an attack on Volney's Loi naturelle, in which the author was said to 'deify egoism' ${ }^{68}$ In Britain, those themes were carried less by secular philosophers than by professional clergymen, but the accusations were frequently the same. ${ }^{69}$

Volney's eschatology carried a popular politics with it too. And despite critics' focus on Volney's historiography, theology and morality, this politics played a crucial role in its reception. Contemporary evidence suggests that the single most influential part of the entire book was a stylised parable of popular liberation in which the people of France, and then the world, rise up to confront their oppressors and to demand social reform in the form of an adjustment of society to coincide with the dictates of natural law. This chapter, labelled 'The

64 Almanac de la Franc-Maçonnerie (1886, Angers), cited in Mathiez, A. 1904, La Théophilanthropie et le Culte Décadaire, 1796-1801, Alcan, Paris, p. 610. In 1911, a lodge in the town of Laval in the Mayenne was named after Volney. It still operates. See: <www.godf.org >

65 Damiron, J. P. 1828, Essai sur l'Histoire de la philosophie au dix-neuvième siècle, Ponthieu, Paris, p. 134.

66 See: de Staël, G. 1871 [1813], 'De l'allemagne', in Oeuvres complètes de Madame la Baronne de StaëlHolstein, [3 vols], Didot-Freres, Paris, vol. II, p. 204; Bernardin de Saint-Pierre, J. H. 1818, 'De la nature de la morale', in Oeuvres complètes de Jacques-Henri-Bernardin de Saint-Pierre, [12 vols], Méquignon-Marris, Paris, vol. VII, pp. 424-30; Constant, B. 1824-31, De la Religion, considérée dans sa source, ses formes et ses développements, [ 5 vols], Bossange, Paris, vol. I, book 1, chs 1, 2 and 4, and book II, chs 5 and 7.

67 Perhaps the most extended critical treatment of Volney's work from among the followers of Victor Cousin can be found in Damiron, J. P. 1828, Essai sur l'histoire de la philosophie au dix-neuvième siècle, Ponthieu \& Compagnie, Paris, p. 129.

68 Renouard, C. 1820, 'Enseignement du droit', Thémis, ou Bibliothèque du jurisconsulte, pp. 2, 292.

69 Perhaps the most developed philosophical reflections on Volney's moral system in Britain were contained in Priestley, Observations on the Increase of Infidelity and Letters to Mr Volney. 
new age', was reproduced widely in the French press during the time of the Revolution - perceived as an allegory of the rise of the Third Estate in 1789. In Britain, it was reproduced almost endlessly as a popular pamphlet within the radical community from the mid-1790s until the 1840s. A catalogue of figures and groups who made use of this aspect of Volney's work during this period would list a substantial proportion of English radical activists. To name only the most prominent, we can find regular favourable reference to Volney among the London Corresponding Society, the Johnson circle and the followers of the agrarian socialist Thomas Spence during the 1790s. In the postwar era, Volney was embraced by Richard Carlile and his Zetetic movement, Thomas Wooler, John Wade, Thomas Davison, Robert Taylor and the Owenite and future president of the British secularist movement, James Watson. We could take this influence right through to Chartist groups associated with both Feargus $\mathrm{O}^{\prime}$ Connor and George Julian Harney during the 1830s and 1840s. ${ }^{70}$

With a Manichean division between the industrious populace and the parasitic drones that fed on them, this chapter played an important role in shaping the rhetoric of various kinds of reformist and revolutionary politics in Europe throughout the first half of the nineteenth century. The historian Edward Thompson claimed that it was from this chapter that the sociology of British radical theory was derived. This is clearly an exaggeration. This rhetoric had longer-term origins in both Britain and France. This social typology, in which the key marker of division was between those who performed useful work and those who did not, fed, however, into not just British radicalism, but the industrialiste movement in France during the restoration and into the Saint-Simonian brand of socialism that followed it. In Britain, it fed into the cooperative libertarian politics of Thomas Hodgskin, the mutualist utilitarianism of William Thompson and the communitarian communism of Robert Owen.

What all these thinkers had in common was a belief that the interests of the individual and those of society could be made to coalesce and that for this reason, the morality and politics of 'virtue' in the classical sense-like the morality and politics of authority - were unnecessary and destructive. The practical implications of this doctrine were, however, often remarkably vague. For some thinkers in this tradition, the doctrine seemed to imply a kind of anarchic libertarianism, in which the political power of the oppressors was removed to allow the naturally benevolent dynamics of civil society to unfold. For others, it implied a managerialist approach to politics and economics, in which the mechanisms by which individuals were rewarded for social contribution would be carefully calibrated to ensure justice and fairness. There were prolonged and violent battles to determine the classification of specific social occupations into the categories of industrious citizen or exploitative parasite. In many cases,

70 For an account of Volney's reception in England, see Cook, 'Reading revolution', pp. 125-46. 
these debates came to centre on the figure of the capitalist entrepreneur or the mercantile middleman. More broadly, they focused on the question of how it might be possible to ensure equitable exchange in the commerce of social life. For many, by the 1820s, solving this problem was perceived to be the key to realising the new age of justice, liberty and global fulfilment fleetingly promised by the advent of the French Revolution and yet seemingly deferred.

In 1844, when Karl Marx and Friedrich Engels wrote about the history of what they called 'French materialism', they argued that it had two strands. One, they claimed, derived from Cartesian physics and passed, by stages, through La Mettrie and Cabanis into the realm of modern medicine. The other was typified by Helvétius and by a moral philosophy of interest alignment that evolved, in their view, from Lockean associationism. This latter strand, they believed, led 'directly to socialism and communism'. They expounded the argument in some detail:

There is no need of any great penetration to see from the teaching of materialism on the original goodness and equal intellectual endowment of men, the omnipotence of experience, habit and education, and the influence of environment on man, the great significance of industry, the justification of enjoyment etc. how necessarily materialism is connected with communism and socialism...If correctly understood interest is the principle of all morality, man's private interest must be made to coincide with the interest of humanity...If man is social by nature he will develop his true nature only in society. ${ }^{71}$

In England, they traced this evolution from Helvétius through Bentham to Robert Owen. In France, they nominated Volney as an intermediary in a line of development culminating in figures such as Théodore Dezamy and Jules Gay. ${ }^{72}$ They accompanied the analysis with lengthy quotations, approvingly presented, from Helvétius, Holbach and Bentham. ${ }^{73}$

By the next year, Marx and Engels had seemingly changed their minds. The role assigned to this tradition in their account of the evolution of socialism

71 Marx, K. and Engels, F. 1975-2004, 'The holy family, or critique of critical critique', in K. Marx and F. Engels, Collected Works of 1844-45, [50 vols], Lawrence \& Wishart, London, vol. IV, p. 130.

72 The former was an outspokenly 'materialist' communist, author of works such as Code de la communauté (1842, Paris) and an implacable opponent of Etienne Cabet. The latter was a French disciple of Robert Owen who founded the journal Le Communiste in the late 1840s. On these two in their context, see: Maillard, A. 1999, La communauté des Égaux: Le communisme néo-Babouviste dans la France des années 1840, Kimé, Paris.

73 Marx and Engels, 'The holy family', pp. 178-9. 
was discarded. Instead, this philosophy was now the 'historically justified philosophical illusion about the bourgeoisie just then developing in France'. In the two philosophes, Helvétius and Holbach, the 'thirst for exploitation could still be described as a thirst for the full development of individuals in conditions of intercourse freed from the old feudal fetters', but its destiny was Bentham, in whom the 'complete subordination of all existing relations to the relation of utility' was the ideological expression of a bourgeoisie in the flush of power. ${ }^{74}$

This account of the historical function of this tradition of political and moral thought would come to dominate later scholarship. Fused in the Anglophone world with the critiques by very different figures, such as Thomas Carlyle, Charles Dickens or William Blake, it evolved to the point where it became standard practice to link the critique of capitalism, however motivated, to a critique of utilitarianism, its predecessors and offshoots - a category to which all forms of sensationist moral and political philosophy were assimilated.

Despite the general retreat from rigorous forms of Marxism in recent times, this historical cliché has largely survived. As an analysis of the process of European intellectual history, however, it is flawed. Neither the account in The Holy Family nor that in The German Ideology captures the political and intellectual history of 'French materialism' or, more broadly, sensationist political philosophy. That history is too complex to be characterised by a teleology that links it directly either to socialism or to free-market utilitarianism. In the case of Volney, at least, the reception of his thought can be traced through paths that lead to both and to neither.

How do we explain the diverse political visions among those who expressed a debt to Volney's work or made use of his texts? In part it reflects the practicalities of political struggle and the ambiguities of philosophical discourse.

Volney's political eschatology was, like many others', significantly clearer about the evils to be overcome in the future state than about the form that state might take. Throughout the first half of the century, many features of Volney's world view remained central to campaigns for social reform. These include: the appeal to natural law against arbitrary convention; the designation of force and fraud as the principal tools of oppression; the insistence that all citizens should perform useful work; the notion of social reciprocity; and the dream of building a society in which the interests of all would be reconciled. Those who used this language did not, however, necessarily share social goals. The struggle between them took the form of conflict and negotiation over the definition, or implication, of terms whose normative power was largely unchallenged.

74 Marx, 'The German ideology', pp. 203-4. 
Understanding this process helps us to see why Volney's often vague parable of human emancipation and social perfectibility was able to retain affective force for a prolonged period. Although in some respects idiosyncratic, it tapped into a code of quasi-secular history and prophecy whose narrative force continued to inspire political theorists and political movements for generations. Its strategic silences, while they served a period purpose, had the consequence that its ultimate promise was, and to some extent remains, a matter of dispute.

Volney's most influential work, The Ruins, was not a paradigm-creating work of philosophical exposition. It was rhetorical, poetic, pragmatic and political in intent. This character enhanced its contemporary power but contributed to its long-term neglect. Volney is not remembered as one of the great intellectual system builders of his era. He is, however, a thinker who is worth more attention than he has been granted by modern scholars. Both his thought and the history of its reception offer us a way into thinking about some of the complex relationships between politics, religion and the emergent social sciences in a formative era for the modern history of all three. It is in this sense that it is appropriate to think of Volney as a key thinker. 